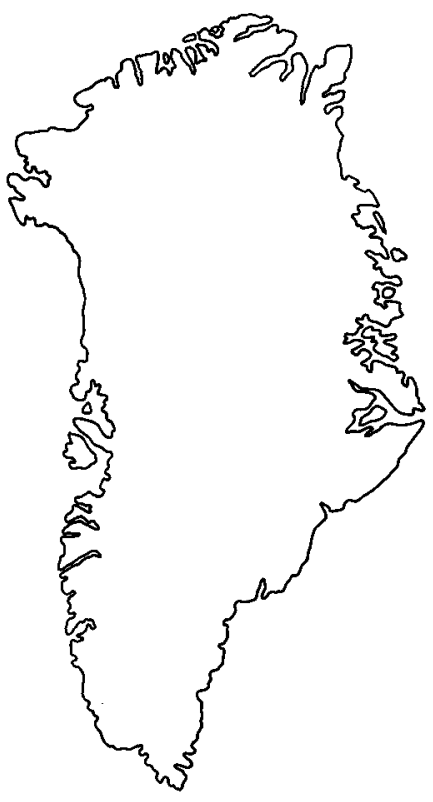

\title{
Hadimopanella apicata from the Lower Cambrian of western North Greenland
}

\author{
John S. Peel and Niels H. Larsen
}

\begin{abstract}
Microscopic button-shaped phosphatic problematic fossils referred to Hadimopanella apicata Wrona 1982 are described from Lower Cambrian carbonates in the Nyeboe Land fault zone, western North Greenland. The species is otherwise known from southern Spitsbergen, and in both areas it is associated with Serrodiscus, Calodiscus, olenellids and other fossils. Unlike the type suite, Greenland specimens of Hadimopanella apicata show a tendency toward differentiation of several nodes in the apical area of the supposed outer surface.
\end{abstract}

J. S. P. and N. H. L., Grønlands Geologiske Undersøgelse, Øster Voldgade 10, DK-1350 København K, Danmark.

Hadimopanella is a small $(40-460 \mu \mathrm{m})$ phosphatic button of uncertain biological affinities originally briefly described by Gedik (1977) from the Middle (and ?Lower) Cambrian of Turkey (Gedik, 1981). Almost simultaneously with the publication of this first account, Bengtson (1977) gave a full description of closely similar material from the Lower Cambrian of Siberia under the name Lenargyrion knappologicum. The better described Lenargyrion thus appears to be a junior subjective synonym of Hadimopanella (Wrona, 1982; van den Boogaard, 1983), although the species oezgueli of Gedik (1977) and knappologicum of Bengtson (1977) may prove to be distinct (Bengtson, 1977, pp. 760-761, note added in proof).

Hadimopanella oezgueli has subsequently been recorded from the Middle Cambrian Lancara Formation of Spain by van den Boogard (1983), while Wrona (1982) described a further species, Hadimopanella apicata, from the Lower Cambrian of southern Spitsbergen. H. apicata is here recorded from Lower Cambrian strata occurring in the Nyeboe Land fault zone of Nyeboe Land, western North Greenland (see Dawes \& Peel, this report; fig. 1). Ryszard Wrona (written communication) is currently investigating similar material from Cambrian erratics from the Antarctic.

Utahphospha is a problematic cone-shaped, phosphatic micro-fossil (1 $\mathrm{mm}$ in diameter), first described from the Upper Cambrian of the western United States (Müller \& Miller, 1976). The outer surface of Utahphospha is covered by closely juxtaposed circular sequins. Individual 'sequins' are clearly similar to the 'buttons' of Hadimopanella, as pointed out by Repetski (1981) in his description of a second species of Utahphospha from the Lower

Rapp. Grønlands geol. Unders. 121, 89-96 (1984)

7 'Rapport nr. 121 


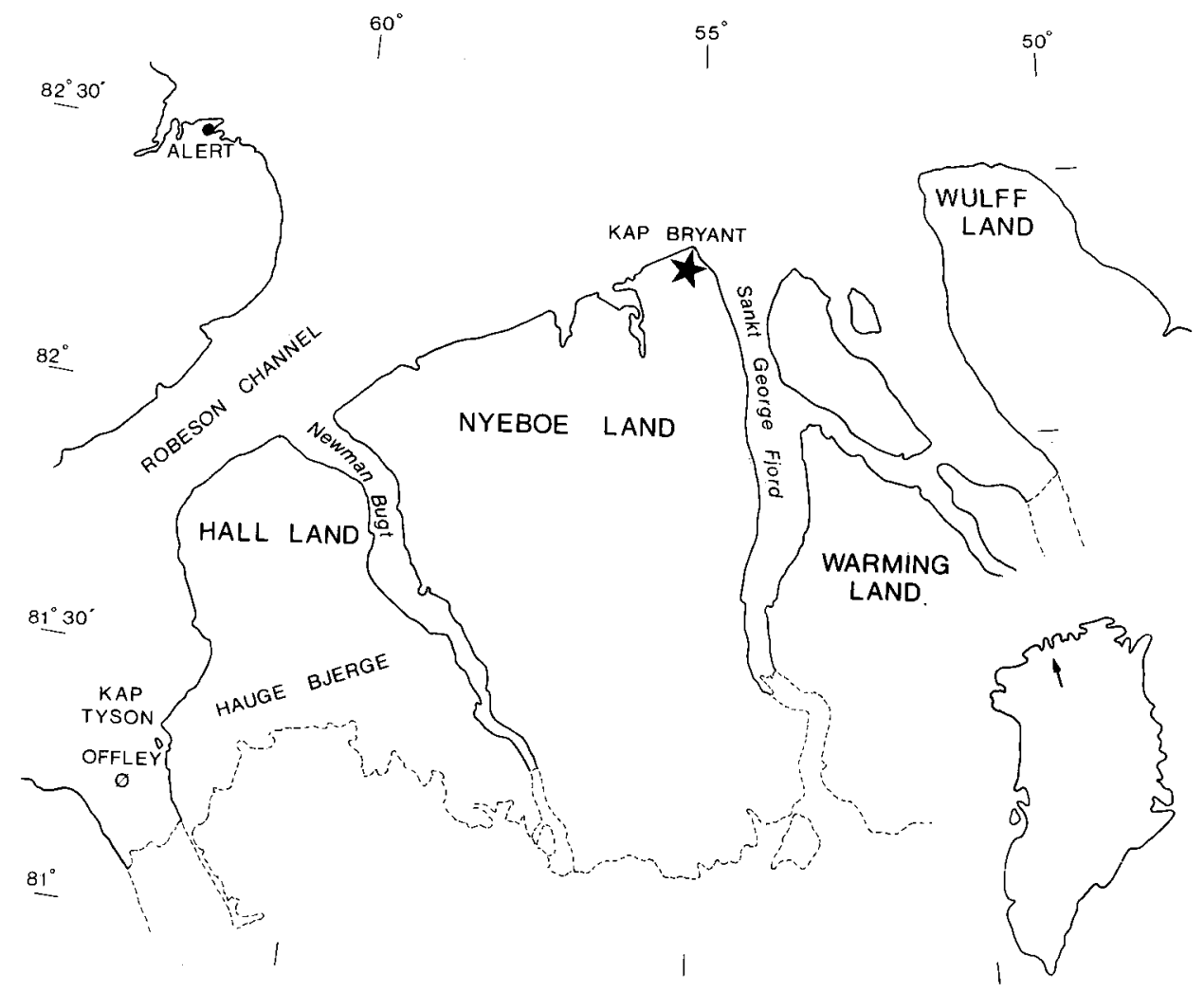

Fig. 1. Collection locality (star) for Hadimopanella apicata, south of Kap Bryant, Nyeboe Land.

Ordovician of western Texas. Indeed, Repetski commented that Hadimopanella may be a junior synonym of Utahphospha. The biological affinities of Hadimopanella and Utahphospha are not known. Müller \& Miller (1976) considered Utahphospha to be a possible hatched cyst, since the tip of the phosphatic cone was perforated from the inside. Bengtson (1977) has discussed interpretation of Lenargyrion (= Hadimopanella) as both an operculum for some kind of tube dwelling organism and as an external dermal sclerite. The general form of the buttons tends to support the latter interpretation, a view reinforced by the occurrence of a capping layer which is also often abraded on the presumed outer surface, and also by comparison to Utahphospha. Bengtson (1977) speculated on the question of

Fig. 2. Hadimopanella apicata, Lower Cambrian, Nyeboe Land. Scanning electron micrographs. A,B, MGUH 16.544 from GGU sample 83338, upper surface showing well developed brim and mineral overgrowth, $\times 600$. C, MGUH 16.545 from GGU sample 83338 , heavily mineralised upper surface, $\times$ 400. D,E, MGUH 16.546 from GGU sample 83337, abraded upper surface with adherent mineralisation, $\times 400$. F, MGUH 16.547 from GGU sample 83338 , oblique view of convex lower surface, $\times 600$. G,H, MGUH 16.548 from GGU sample 83338, upper surface with three apical tubercles and well developed brim, $\times 600$. I, MGUH 16.549 from GGU sample 83337, upper surface, $\times 400$. 


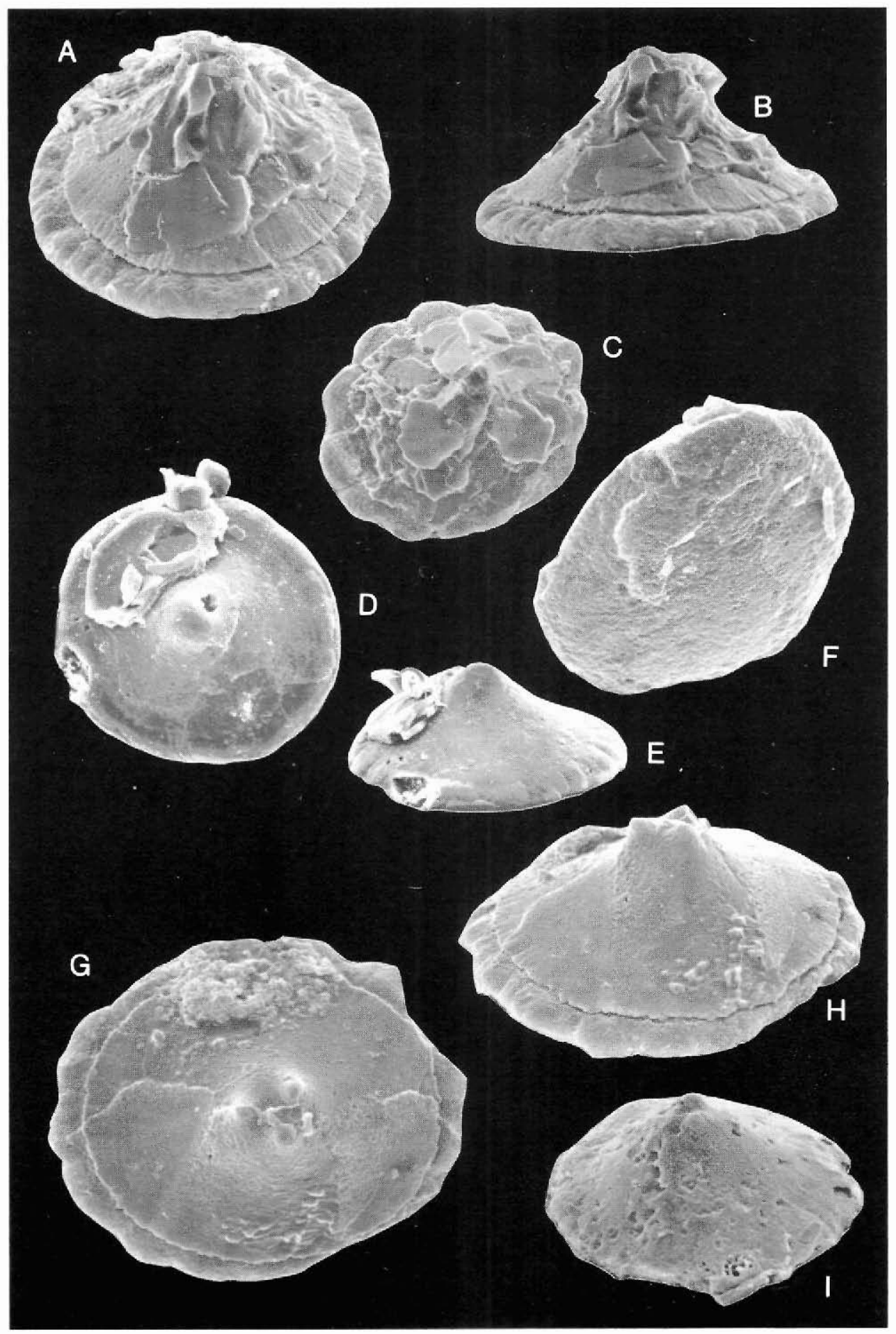




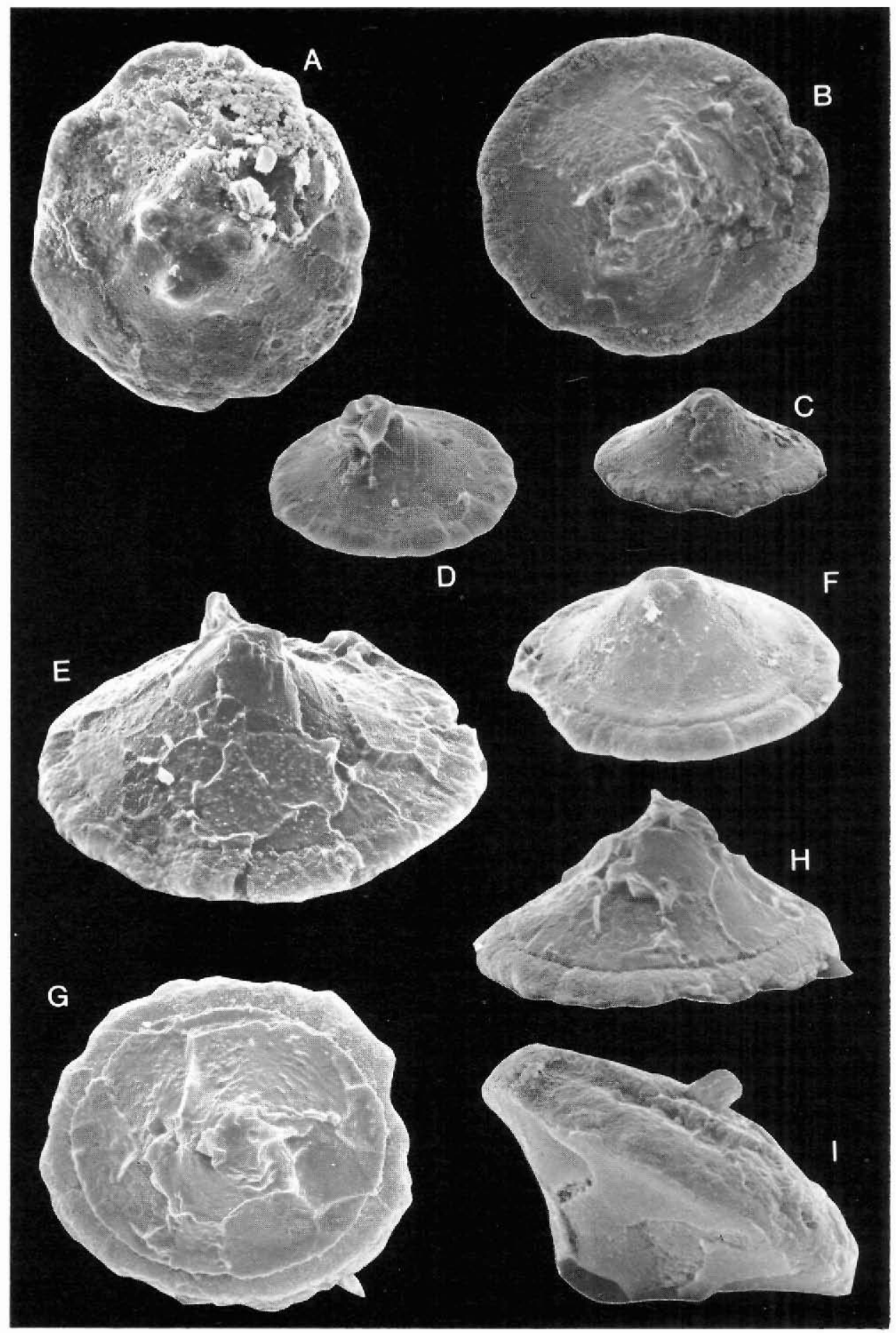


vertebrate affinities for Lenargyrion, but considered the evidence to be inconclusive. Supposed vertebrates of the genus Anatolepis Bockelie \& Fortey 1976 occur in Upper Cambrian and Lower Ordovician strata, but interpretation of these remains is still a subject of some debate (Bockelie \& Fortey, 1976; Repetski, 1978; Peel, 1979; Briggs \& Fortey, 1981; Thompson \& Plotnick, 1981).

\section{Hadimopanella apicata Wrona, 1982}

Figs 2-5

Hadimopanella apicata Wrona, 1982, pp. 9-16, plates 1-4.

Figured material. MGUH 16.544-16.565 from GGU samples 83337-8, collected by P. R. Dawes, south of Kap Bryant, Nyeboe Land, western North Greenland (fig. 1). Figured specimens are deposited in the Geological Museum, Copenhagen.

Other material. Sclerites of Hadimopanella apicata are abundant in the two available residues after acetic acid digestion of GGU samples 83337-8. Both residues result from treatment of less than $200 \mathrm{~g}$ of rock.

External morphology. Preservation is variable, with many specimens showing subsequent mineral overgrowth of the sclerites and apparent partial phosphoritisation of immediately adjacent carbonate grains (figs $2 \mathrm{~A}-\mathrm{C}, 3 \mathrm{E}, \mathrm{G}, \mathrm{H}$ ). All observed examples are essentially complete, but some specimens are chipped around the periphery or appear abraded (fig. $4 \mathrm{~A}$, B) or etched.

Individual sclerites are mainly sub-circular to slightly oval, with a long axis : short axis ratio of maximum 6:5. The presumed lower surface is shallowly convex and passes via the rounded periphery onto the more strongly vaulted upper surface. The degree of elevation of the upper surface varies from about one third to more than two thirds of the diameter.

The lower surface is smooth. The upper surface is dominated by the central cap which is surrounded by a well developed peripheral brim (fig. 2A,B), the basal margin of Wrona (1982). This brim is commonly radially corrugated, but some specimens show a fibrous structure, probably as a result of etching (fig. $3 \mathrm{~B}, \mathrm{C}$ ). The basal suture is often conspicuous, which may also reflect etching, as is a fine corrugation of the cap immediately adjacent to the suture (fig. 2A,B). The upper surface is dominated by the central apex, from which the surface falls away with concave curvature toward the periphery. The apex shows a tendency to differentiate into up to four (possibly five) small tubercles (e.g. fig. 3A). About one

Fig. 3. Hadimopanella apicata, Lower Cambrian, Nyeboe Land. Scanning electron micrographs. A, MGUH 16.550 from GGU sample 83337, upper surface with four tubercles, $\times 600$. B,C, MGUH 16.551 from GGU sample 83338, upper surfaces with etched(?) fibrous brim; $B, \times 600, C, \times 400$. D, MGUH 16.552 from GGU sample 83338, upper surface with radially corrugated brim, $\times 400$. E, MGUH 16.553 from GGU sample 83338, with mineral overgrowth on upper surface along boundaries with adjacent crystals, $\times 600$. F, MGUH 16.554 from GGU sample 83337, slightly eroded upper surface showing four apical tubercles and well developed brim, $\times$ 400. G,H, MGUH 16.555 from GGU sample 83338, upper surface with mineral growth along boundaries of adjacent crystals, $\times 600$. I, MGUH 16.556 from GGU sample 83338, lateral view with the convex under surface (upper right) and vaulted upper surface with concave sides (lower left), $\times 600$. 


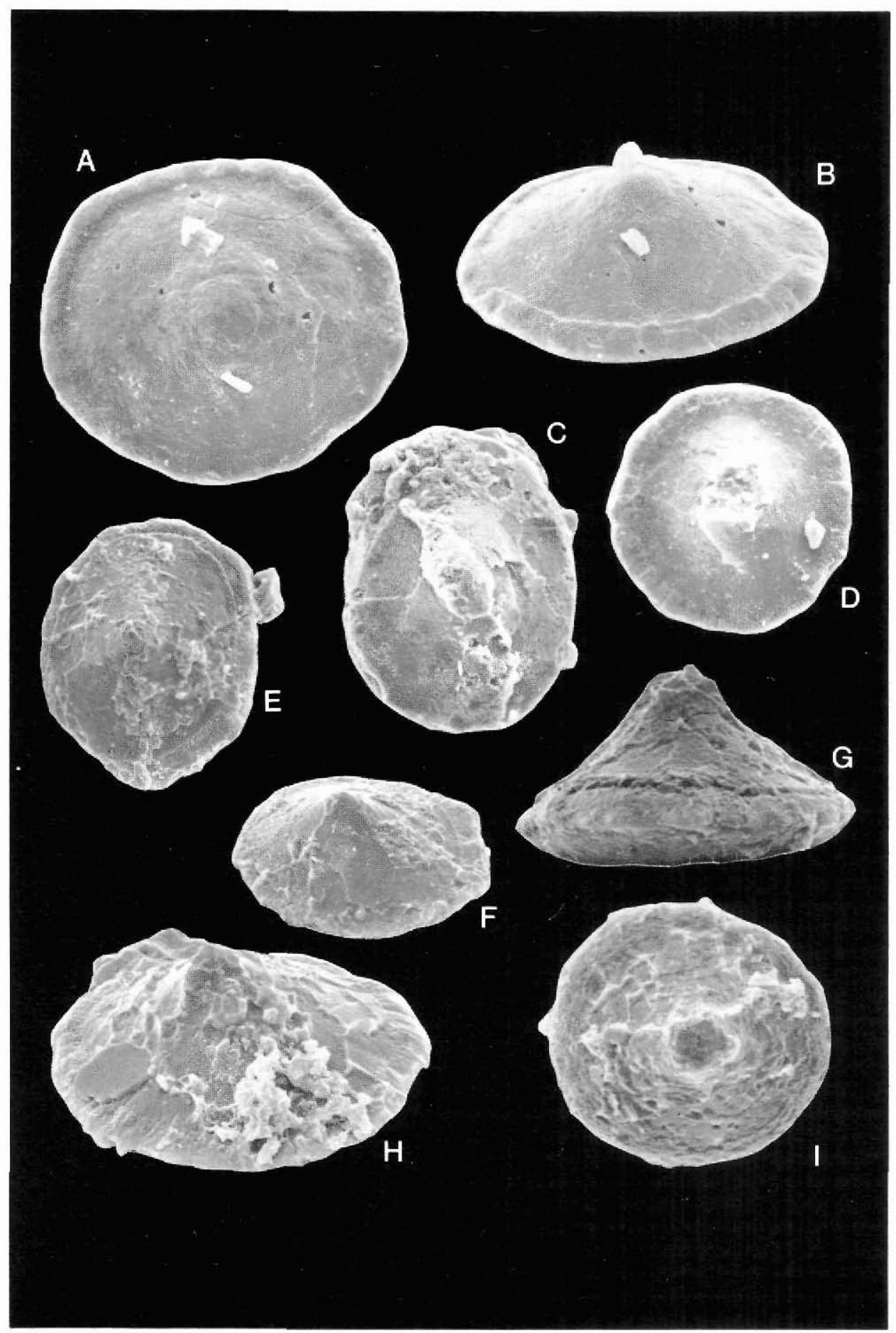



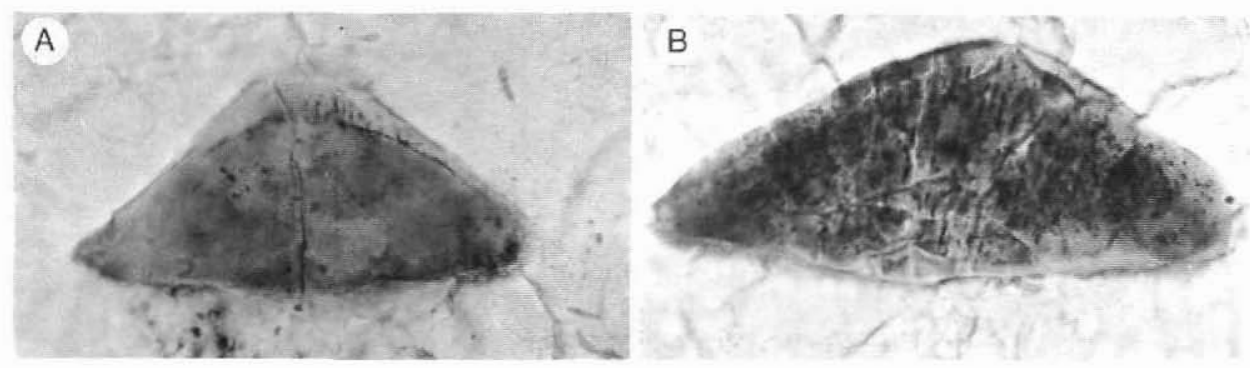

Fig. 5. Hadimopanella apicata, Lower Cambrian, Nyeboe Land, GGU sample 83337. Thin sections, × 600. A, MGUH 16.564 in lateral aspect showing the hyaline cap. B, MGUH 16.565 in lateral aspect showing dark mineralisation in canals(?) in the basal core.

quarter of the 32 specimens examined by scanning electron microscopy show clear differentiation into two or more tubercles, with the great majority showing four tubercles. More than half of the examined samples appear to have an undifferentiated apex, but it should be noted that small tubercles may be concealed within the mineral overgrowth which characterises most specimens to some degree, or in some cases abraded away.

Internal structure. A systematic examination of the internal structure of the Greenland examples of Hadimopanella apicata has not been attempted. A single thin section prepared for lithological study of the original sample shows several random sections, one of which shows the hyaline cap (fig. 5A). In a second cross-section (fig. 5B), dark mineralisation suggests canals in the basal core reminiscent of those illustrated by Bengtson (1977, text-fig. 4).

Discussion. Hadimopanella oezgueli Gedik, 1977, and H. knappologica (Bengtson, 1977) are most readily distinguished from $H$. apicata by the abundance of tubercles on the apical surface, although both Bengtson (1977, text-fig. 1B) and van den Boogaard (1983, fig. 3F) illustrate examples with relatively few tubercles. Examples of $H$. oezgueli and $H$. knappologica also tend to be larger, as noted by Wrona (1982), with individuals reaching more than three times the maximum diameter of about $140 \mu \mathrm{m}$ recorded in $H$. apicata from Greenland.

The brim in most specimens of $H$. apicata is wide and corrugated, while in the other species it is often narrower and with a more fibrous character (e.g. van den Boogaard, 1983, fig. 5). In $H$. apicata, however, it would appear that both the degree of expression of the

Fig. 4. Hadimopanella apicata, Lower Cambrian, Nyeboe Land. Scanning electron micrographs. A,B, MGUH 16.557 from GGU sample 83337, abraded upper surface, $\times$ 400. C, MGUH 16.558 from GGU sample 83337, upper surface of elongate sclerite with mineral overgrowth, $\times 400$. D, MGUH 16.559 from GGU sample 83337, upper surface, $\times$ 400. E,F, MGUH 16.560 from GGU sample 83338, upper surface, $\times 400$. G, MGUH 16.561 from GGU sample 83338, lateral view showing strongly vaulted upper surface and shallowly convex lower surface, $\times 600$. H, MGUH 16.562 from GGU sample 83338, upper surface with mineral overgrowth, $\times 600$. I, MGUH 16.563 from GGU sample 83337, upper surface, $\times 400$. 
brim and its nature varies with abrasion or etching. Wrona (1982, pl. 1, fig. 3) illustrated an example of $H$. apicata in which the cap extended completely to the periphery, over the brim, and similar specimens are known from Greenland (figs $2 \mathrm{E}, 4 \mathrm{~F}$ ). Development of a fibrous brim is also known from Greenland (fig. 3B,C) and may be a reflection of internal structure.

Occurrence. Hadimopanella apicata is known from the Lower Cambrian Blåstertoppen Dolomite Formation of Sørkapp Land, southern Spitsbergen (Wrona, 1982) and from un-named Lower Cambrian carbonates in western North Greenland. In the latter area, it is associated with Serrodiscus bellimarginatus, Calodiscus, pygidia and fragments of an olenellid, Chancelloria, Pelagiella, Latouchella and fragmentary inarticulate brachiopods (see Dawes \& Peel, this report). Wrona (1982, pp. 10-11) records a similar fauna accompanying $H$. apicata in Spitsbergen.

Acknowledgements. Thanks are directed to $\mathrm{S}$. Bengtson for information concerning recent publications on Hadimopanella, and to H. Dissing, University of Copenhagen, for placing a Leitz photomicroscope at our disposal. E. Glendal and B. Thomas assisted in preparation of the manuscript.

\section{References}

Bengtson, S. 1977: Early Cambrian button-shaped phosphatic microfossils from the Siberian Platform. Palaeontology 20, 751-762.

Bockelie, T. G. \& Fortey, R. A. 1976: An early Ordovician vertebrate. Nature, Lond. 260, 36-38. van den Boogaard, M. 1983: The occurrence of Hadimopanella oezgueli Gedik in the Lancara Formation in NW Spain. Proc. K. ned. Akad. Wet. B, 86, 331-341.

Briggs, D. E. G. \& Fortey, R. A. 1981: The cuticle of aglaspid arthropods, a red-herring in the early history of the vertebrates. Lethaia 15, 25-29.

Dawes, P. R. \& Peel, J. S. this report: Biostratigraphic reconnaissance in the Lower Palaeozoic of western North Greenland. Rapp. Grønlands geol. Unders. 121, 19-51.

Gedik, I. 1977: Orta Toroslar'da konodont biyostratigrafisi. Bül. Türk. Jeol. Kurumu 20, 35-48.

Gedik, I. 1981: Hadimopanella Gedik, 1977 'nin stratigrafik dagilimi ve mikroyapisi konusunda bazi gözlemler. Karadeniz Tek. Univ. Yer Bilimleri Dergisi, Jeol. 1(2), 159-163.

Müller, K. J. \& Miller, J. F. 1976: The problematic microfossil Utahphospha from the Upper Cambrian of the western United States. Lethaia 9, 391-395.

Peel, J. S. 1979: Anatolepis from the Early Ordovician of East Greenland - not a fishy tail. Rapp. Grønlands geol. Unders. 91, 111-115.

Repetski, J. E. 1978: A fish from the Upper Cambrian of North America. Science 200, 529-531.

Repetski, J. E. 1981: An Ordovician occurrence of Utahphospha Müller \& Miller, J. Paleont. 55, 395400 .

Thompson, D. \& Plotnick, R. E. 1981: Cambrian vertebrates: are they arthropods? Geol. Soc. Am. Abstracts with Programs 13(7), 566 only.

Wrona, R. 1982: Early Cambrian phosphatic microfossils from southern Spitsbergen (Hornsund region). Palaeontologica Polonica 43, 9-16. 